\title{
KAJIAN KAPASITAS INFILTRASI LAHAN JERUK DAN KARET DI DAERAH PASANG SURUT DESA SEBAWI KABUPATEN SAMBAS
}

\author{
STUDY ON INFILTRATION CAPACITY OF CITRUS AND RUBBER ORCHARD IN THE \\ TIDAL AREA IN SAMBAS DISTRICT SEBAWI VILLAGE
}

Rendi Saputra, Tino Orciny Chandra, dan Junaidi

\begin{abstract}
Program Studi Ilmu Tanah Fakultas Pertanian Universitas Tanjungpura, Pontianak
\end{abstract}
Jln. Prof. Dr. Hadari Nawawi, Pontianak, 78124, Indonesia.

Email: rendi.saputra@gmail.com

\begin{abstract}
ABSTRAK
Penelitian ini bertujuan untuk mempelajari laju atau kapasitas infiltrasi pada lahan yang berbeda (lahan jeruk dan lahan karet) pada wilayah pasang surut di Desa Sebawi Kabupaten Sambas. Pengukuran laju infiltrasi dilakukan pada 4 titik pengukuran tiap lahan, sehingga diperoleh 8 titik pengukuran. Laju infiltrasi diukur dengan menggunakan alat infiltrometer cincin ganda. Keberadaan vegetasi seperti rerumputan memberikan perbedaan laju infiltrasi yang nyata. Dari hasil pengukuran di lapangan, diperoleh pengukuran laju infiltrasi pada lahan jeruk pada saat pasang yaitu $11,78 \mathrm{~cm} / \mathrm{jam}$ sedangkan pada lahan karet $4,79 \mathrm{~cm} / \mathrm{jam}$ dan pada saat surut laju infiltrasi lahan jeruk $15,30 \mathrm{~cm} / \mathrm{jam}$ sedangkan di lahan karet $8,58 \mathrm{~cm} / \mathrm{jam}$. Dari hasil analisis laboratorium yang dilakukan bahwa tekstur tanah di dominasi oleh liat, dan menunjukkan t hitung pada lahan jeruk dan lahan karet bahwa bobot isi, porositas, kadar air, berat jenis partikel dan permeabilitas tanah tidak berbeda nyata terhadap $\mathrm{t}$ tabel. Tanaman penutup tanah seperti rerumputan sangat membantu meningkatkan porositas tanah, sehingga semakin banyak tanaman penutup tanah dan rerumputan maka laju infiltrasi semakin baik.
\end{abstract}

Kata kunci : Lahan, Infiltrasi, Permeabilitas, Kebun, Infiltrometer ring ganda.

\begin{abstract}
This research aims to study the infiltration capacity of two different land (citrus and rubber orchard) in the tidal area in Sambas district Sebawi village. Infiltration rate measurements performed on 4 point measurement in the land, in order to obtain 8 points of measurement. Infiltration rate was measured using a double ring infiltrometer tool. The presence of vegetation give significant differences in the rate of infiltration. The infiltration rate at high tide was $11.78 \mathrm{~cm} / \mathrm{hour}$ in citrus and $4.79 \mathrm{~cm} / \mathrm{hour}$ in rubber, while at low tide infiltration in the orange's land $15.30 \mathrm{~cm} / \mathrm{hour}$ while in the rubber's land $8.58 \mathrm{~cm} /$ hour. From the results of laboratory analysis conducted that the texture of the soil is dominated by clay, and shows $t$ count on orange's land and rubber's land that bulk density, porosity, water content, particle density and soil permeability is not significantly different to the $T$ table. Cover crops like grasses help increase the volume of soil porosity, so that more cover crops as grasses, the infiltration rate become better.
\end{abstract}

Keywords : Land, Infiltration, Permeability, garden, double ring infiltrometer. 


\section{PENDAHULUAN}

Lahan mengalami perubahan dari waktu ke waktu seiring meningkatnya kebutuhan manusia akan lahan. Perubahan tersebut dikarenakan pemanfaatan lahan untuk kepentingan hidup manusia. Pengembangan lahan pasang surut merupakan alternatif pilihan yang sangat strategis untuk mengatasi tantangan peningkatan produksi dan alih fungsi lahan-lahan pertanian menjadi lahan non pertanian. Lahan pasang surut memiliki prospek yang sangat besar untuk dikembangkan dan merupakan pilihan strategis dalam menghadapi tantangan peningkatan produksi pertanian yang semakin kompleks.

Lahan rawa pasang surut adalah suatu wilayah rawa yang dipengaruhi oleh gerakan pasang surut air laut yang secara berkala mengalami luapan air pasang. Terdapat $\pm 2,94$ juta ha potensi lahan rawa di Kalimantan Barat atau $8,8 \%$ dari total 33,4 juta ha lahan rawa yang ada di Indonesia. Penggunaan lahan yang berbeda berarti penutupan tanah yang berbeda mempengaruhi laju infiltrasi yang terjadi.

Menurut Badan Pusat Statistik Kabupaten Sambas tahun 2013, luas tanaman perkebunan dari tanaman karet adalah \pm 200 ha, sedangkan tanaman komoditi unggulan buahbuahan yang dikembangkan khusus untuk Desa Sebawi terutama tanaman jeruk memiliki luas sebesar \pm 77 ha.

Infiltrasi adalah proses aliran air, (umumnya berasal dari curah hujan), masuk kedalam tanah. Setelah lapisan tanah bagian atas jenuh, kelebihan air tersebut mengalir ke bagian tanah yang lebih dalam sebagai akibat gaya gravitasi bumi dan dikenal sebagai proses perkolasi (Asdak, 2002).

Infiltrasi air hujan pada daerah bervegetasi akan lebih besar bila dibandingkan dengan daerah yang tidak bervegetasi, sebab vegetasi tersebut menghasilkan serasah yang dapat meningkatkan porositas tanah. Serasah dan sistem perakaran pohon ternyata memililiki peranan yang cukup banyak dari segi hidrologi misalnya meningkatkan kapasitas infiltrasi, dan meningkatkan perkolasi (Hamilton dan King, 1988 dalam Indriyanto, 2012).

Infiltrasi tanah pada lahan pasang surut memasuki pada musim hujan yang berlangsung dari sekitar Oktober/November sampai dengan Maret/April, air tanah berangsur naik ke permukaan, dan tergantung kondisi tata air makro dan mikro, seringkali dapat menggenangi tanah (Subagyo, 1997).

Berkaitan dengan hal tesebut, perlu dilakukan penelitian tentang kajian terhadap kapasitas infiltrasi pada tipe pemanfaatan lahan yang berbeda pada lahan pasang surut

\section{METODE PENELITIAN}

Penelitian ini dilaksanakan di Desa Sebawi Kabupaten Sambas. Lokasi penelitian ini merupakan daerah dataran rendah yang tergolong daerah pasang surut tipe luapan C. Penelitian berlangsung pada bulan April sampai bulan Mei 2014. Bahan yang digunakan adalah (1) peta lokasi penelitian skala $1: 100.000$, (2) peta titik pengamatan skala $1: 10.000$, (3) peta jenis tanah skala 1:100.000, dan (4) sampel tanah utuh dan terganggu masing-masing kedalaman $0-20 \mathrm{~cm}$ dan $20-40 \mathrm{~cm}$. Alat yang digunakan adalah bor tanah, ring sampel, meterán kayu pengukur, penggaris, kamera, kompas/GPS, karet gelang, infiltrometer ring ganda, oven, alat tulis dan kertas label.Metode yang digunakan merupakan metode survey lapangan. Terdapat 8 titik pengamatan, dimana 4 titik pengamatan di kebun jeruk dan 4 titik pengamatan di kebun karet. Jarak titik pengamatan ke 1 adalah $10 \mathrm{~m}$ dari saluran sungai, sedangkan jarak titik pengamatan ke 2 adalah $50 \mathrm{~m}$ dari saluran sungai, begitu juga dengan titik pengamatan ke 3 yaitu $10 \mathrm{~m}$ dari saluran sungai dan titik pengamatan ke 4 adalah $50 \mathrm{~m}$ dari saluran sungai. Titik pengamatan ke 1 dan ke 2 adalah sejajar dengan titik pengamatan ke 3 dan ke 4 . Penentuan titik pada kebun jeruk sama dengan penentuan titik pada kebun karet. Selanjutnya pengukuran laju infiltrasi dilakukan pada saat pasang dan saat surut waktu pengukuran mulai pertengahan bulan April pada tanggal 13 April/ 13 di bulan Arab (Hijriah) saat pasang, sedangkan pada tanggal 14-15 april/14-15 purnama saat air surut di bulan Arab (Hijriah). Pengukuran dilakukan saat pasang tanggal 13 $\mathrm{H}$ dan saat surut yakni $15 \mathrm{H}$ pada bulan purnama (bulan Arab). 


\section{HASIL DAN PEMBAHASAN}

\section{Hasil}

Hasil anaisis di laboratorium yang terdiri dari tekstur, bobot isi, kadar air, porositas, berat jenis partikel, dan permeabilitas tanah dapat dilihat pada Lampiran.

Hasil perhitungan uji $\mathrm{t}$ rerata laju infiltrasi $(\mathrm{cm} / \mathrm{jam})$ saat pasang dann surut pertitik di kebun jeruk dan kebun karet dapat dilihat pada Tabel 1.
Hasil perhitungan persamaan laju infiltrasi dan infiltrasi kumulatif di lapangan pada kebun jeruk dan kebun karet dapat dilihat pada Tabel 2 dibawah ini :

Kedalaman muka air tanah pada kebun jeruk dan karet di Desa Sebawi Kabupaten Sambas selama penelitian dapat dilihat pada Tabel 3 di bawah ini:

Tabel 1. Hasil hitung uji t rerata laju infiltrasi $(\mathrm{cm} / \mathrm{jam})$ saat pasang dan surut pertitik di kebun jeruk dan karet.

\begin{tabular}{|c|c|c|c|c|c|}
\hline \multirow{3}{*}{ Titik pengamatan } & \multirow{3}{*}{$\begin{array}{c}\text { Jarak dari } \\
\text { saluran }\end{array}$} & \multicolumn{4}{|c|}{ Laju infiltrasi (cm/jam) } \\
\hline & & Kebun jeruk & Kebun karet & Kebun jeruk & Kebun karet \\
\hline & & Pasang & Pasang & Surut & Surut \\
\hline (1) & $10 \mathrm{~m}$ & 9,74 & 4,99 & 15,88 & 7,95 \\
\hline (2) & $50 \mathrm{~m}$ & 12.19 & 5,09 & 17,14 & 8,26 \\
\hline (3) & $10 \mathrm{~m}$ & 10,01 & 5,68 & 10,94 & 11,71 \\
\hline (4) & $50 \mathrm{~m}$ & 15,15 & 3,41 & 17,24 & 6,43 \\
\hline \multicolumn{2}{|l|}{ Rerata } & 11,78 & 4,79 & 15,30 & 8,58 \\
\hline \multicolumn{2}{|c|}{$\mathrm{t} \mathrm{Tab}=2,47$} & \multicolumn{2}{|c|}{$\mathrm{t} \mathrm{Hit}=5,19^{*}$} & \multicolumn{2}{|c|}{$\mathrm{t} \mathrm{Hit}=3,61^{*}$} \\
\hline
\end{tabular}

Keterangan : $*$ = berbeda nyata

Sumber : Pengukuran di Lapangan

Tabel 2. Persamaan Laju Infiltrasi dan Infiltrasi Kumulatif tiap titik pengamatan.

\begin{tabular}{clcc}
\hline \multirow{2}{*}{ Kebun } & Kode & Laju infiltrasi & Laju infiltrasi \\
\cline { 3 - 4 } & A1 Pasang & $1,1962 \mathrm{t}^{-0,5}-0,05$ & $\mathrm{~cm} /$ jam \\
\hline \multirow{5}{*}{ Jeruk } & A1 Surut & $1,5554 \mathrm{t}^{-0,5}-0,01$ & $2,3925 \mathrm{t}^{0,5}-0,05 \mathrm{t}$ \\
& A2 Pasang & $1,6042 \mathrm{t}^{-0,5}-0,03$ & $3,1109 \mathrm{t}^{0,5}-0,01 \mathrm{t}$ \\
& A2 Surut & $1,6936 \mathrm{t}^{-0,5}-0,01$ & $3,2084 \mathrm{t}^{0,5}-0,03 \mathrm{t}$ \\
& A3 Pasang & $1,1621 \mathrm{t}^{-0,5}-0,04$ & $3,3872 \mathrm{t}^{0,5}-0,01 \mathrm{t}$ \\
& A3 Surut & $1,5587 \mathrm{t}^{-0,5}-0,09$ & $2,3242 \mathrm{t}^{0,5}-0,04 \mathrm{t}$ \\
& A4 Pasang & $1,6562 \mathrm{t}^{-0,5}-0,04$ & $3,1174 \mathrm{t}^{0,5}-0,09 \mathrm{t}$ \\
& A4 Surut & $1,4124 \mathrm{t}^{-0,5}-0,04$ & $3,3124 \mathrm{t}^{0,5}-0,04 \mathrm{t}$ \\
Karet & B1 Pasang & $0,1349 \mathrm{t}^{-0,5}-0,06$ & $2,8248 \mathrm{t}^{0,5}-0,04 \mathrm{t}$ \\
& B1 Surut & $0,0942 \mathrm{t}^{-0,5}-0,12$ & $0,2698 \mathrm{t}^{0,5}-0,06 \mathrm{t}$ \\
& B2 Pasang & $-0,0130 \mathrm{t}^{-0,5}-0,07$ & $0,1885 \mathrm{t}^{0,5}-0,12 \mathrm{t}$ \\
& B2 Surut & $0,3380 \mathrm{t}^{0,5}-0,08 \mathrm{t}$ & $-0,026 \mathrm{t}^{0,5}-0,07 \mathrm{t}$ \\
& B3 Pasang & $0,0910 \mathrm{t}^{-0,5}-0,08$ & $0,6761 \mathrm{t}^{0,5}-0,08 \mathrm{t}$ \\
& B3 Surut & $0,1462 \mathrm{t}^{-0,5}-0,17$ & $0,1820 \mathrm{t}^{0,5}-0,08 \mathrm{t}$ \\
& B4 Pasang & $0,0601 \mathrm{t}^{-0,5}-0,05$ & $0,2925 \mathrm{t}^{0,5}-0,17 \mathrm{t}$ \\
& B4 Surut & $0,1852 \mathrm{t}^{-0,5}-0,07$ & $0,1202 \mathrm{t}^{0,5}-0,05 \mathrm{t}$ \\
\end{tabular}

Keterangan : Hasil Perhitungan (2014) 
Tabel 3. Hasil Pengukuran Kedalaman Muka Air Tanah (cm) pada Kebun Jeruk dan Karet pada Saat Pasang dan Saat Surut.

\begin{tabular}{ccccccccc}
\hline \multirow{2}{*}{$\begin{array}{c}\text { Tanggal } \\
\text { pengamatan }\end{array}$} & \multicolumn{9}{c}{ Kedalaman Muka Air Tanah (cm) } \\
& A1 & A2 & A3 & A4 & B1 & B2 & B3 & B4 \\
\hline 13 April 2014 & Pasang & Pasang & Pasang & Pasang & Pasang & Pasang & Pasang & Pasang \\
& 39 & 42 & 37 & 44 & 35 & 40 & 39 & 40 \\
15 April 2014 & Surut & Surut & Surut & Surut & Surut & Surut & Surut & Surut \\
& 43 & 48 & 42 & 50 & 38 & 45 & 41 & 47 \\
\hline
\end{tabular}

Keterangan : Hasil Pengamatan Langsung di Lapangan

\section{Pembahasan}

Dari Tabel 1 diatas menunjukkan bahwa infiltrasi tanah pada kebun jeruk lebih tinggi dibandingkan dengan kebun karet. Hal ini dikarenakan perbedaan laju infiltrasi disebabkan oleh pengaruh vegetasi tanaman penutup jenis rerumputan yang ada pada kebun. Pada penelitian ini keadaan di lapangan pada kebun jeruk banyak terdapat tanaman penutup tanah. Sehingga pangkasan tajuk dari tanaman penutup tanah tersebut dapat memberikan masukan bahan organik. Tumbuhan bawah selain membantu dalam penyerapan dan pengikatan air tanah, perakarannya mampu memperbaiki permeabilitas tanah. Faktor tersebut membantu dalam meningkatkan volume porositas tanah sehingga menurunkan bobot isi tanah. Semakin rendahnya bobot isi tanah, banyaknya ruang kosong tempat air dan udara, maka laju infiltrasi juga semakin besar. Pasang surut air di saluran sungai pada saat pasang dan surut yang jauh berbeda kedalamannya juga dapat mempengaruhi laju infiltrasi pada kebun tersebut. Secara umum laju infiltrasi pada titik 2 dan 4 pada kebun jeruk dan karet lebih besar dari titik yang lainnya. Hal ini dipengaruhi oleh kedalaman muka air sungai yang mengakibatkan tidak konstannya kedalaman muka air tanah pada titik pengamatan tersebut. Oleh karena itu, laju infiltrasi pada saat pasang dan surut dapat dibedakan secara jelas.

Dari hasil pengamatan fluktuasi muka air tanah hanya dipengaruhi oleh gerakan pasang surut air di saluran sungai, sehingga perbedaan yang terjadi pada tiap titik pengamatan disebabkan oleh adanya gerakan pasang surut air saluran sungai yang menaikkan muka air tanah.
Dari tabel 2 persamaan laju infiltrasi dan infiltrasi kumulatif diatas menunjukkan perbedaan rumus infiltrasi, yang disesuaikan dari pasang dan surut. Hal ini dipengaruhi oleh masuknya air ke dalam tanah pada waktu pasang maupun surut. Kondisi pasang menyebabkan masuknya air ke dalam tanah yang terjadi semakin berkurang, yang mana disebabkan kadar air tanah yang meningkat. Sedangkan pada saat surut, kadar air tanah menurun dan menyebabkan masuknya air kedalam tanah meningkat.

Dari tabel 3 dapat dilihat bahwa dengan pengaruh pasang dan surut air di saluran sungai, muka air tanah menjadi tidak stabil. Sehingga muka air tanah pada kebun jeruk dan karet saat pasang dan surut dapat dilihat pada gambar 1 dan 2 dibawah ini :

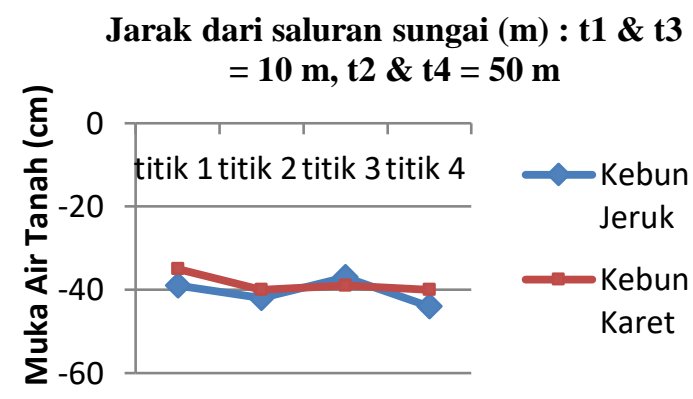

Gambar 1. Hasil Pengukuran Muka Air Tanah (cm) saat pasang 


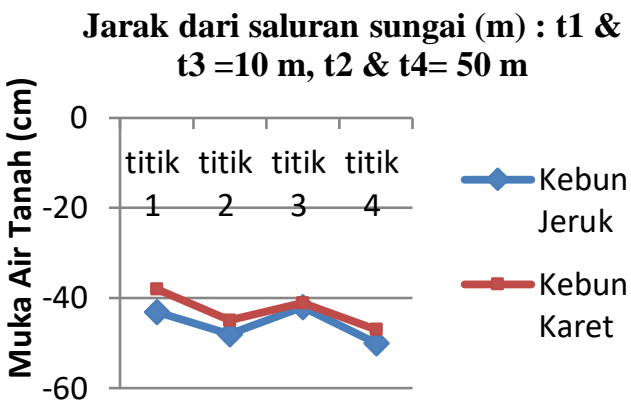

Gambar 2 Hasil Pengukuran Muka Air Tanah (cm) saat Surut

Dari Gambar 1 dan 2 dapat dilihat bahwa dengan pengaruh pasang dan surut air di saluran sungai, muka air tanah menjadi tidak stabil. Pada saat pasang (13 April 2014), kedalaman muka air tanah kebun jeruk lebih tinggi dari pada kedalaman muka air tanah kebun karet. Demikian juga pada pengamatan saat surut (15 April 2014), kedalaman muka air tanah kebun jeruk lebih tinggi dari pada kedalaman muka air tanah kebun karet. Hal ini menunjukkan bahwa pada saat pasang maupun surut muka air tanah dipengaruhi oleh jarak setiap titik pengamatan dengan letak saluran air sungai, semakin jauh titik pengamatan dari saluran air pada saat air pasang maupun surut maka muka air tanah semakin tinggi. Selain hal tersebut juga dikarenakan oleh faktor dari banyaknya vegetasi tumbuhan yang menjukkan perbedaan laju infiltrasi yang nyata. Tumbuhan seperti rerumputan selain membantu dalam penyerapan dan pengikatan air tanah, perakarannya mampu memperbaiki drainase dan permeabilitas tanah. Rerumputan tersebut sangat membantu dalam meningkatkan volume porositas tanah sehingga menurunkan bobot isi tanah. Semakin banyak keragaman vegetasi tumbuhan bawah seperti rerumputan maka laju infiltrasi akan semakin baik (Yogaswara, 2001). Untuk lebih jelasnya nilai rerata laju infiltrasi tiap titik pengamatan saat pasang dan surut dapat dilihat pada gambar 3 dan 4 dibawah ini

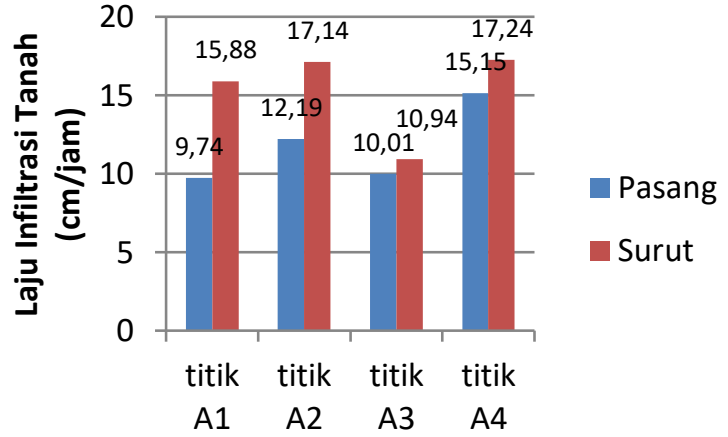

Gambar 3. Rerata Laju Infiltrasi pada Kebun Jeruk tiap titik pengamatan pada Saat Pasang dan Saat Surut

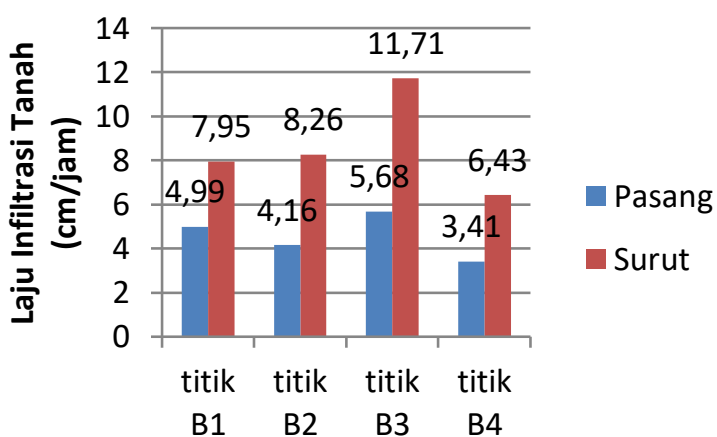

Gambar 4. Rerata Laju Infiltrasi pada Kebun Karet tiap titik pengamatan pada Saat Pasang dan Saat Surut

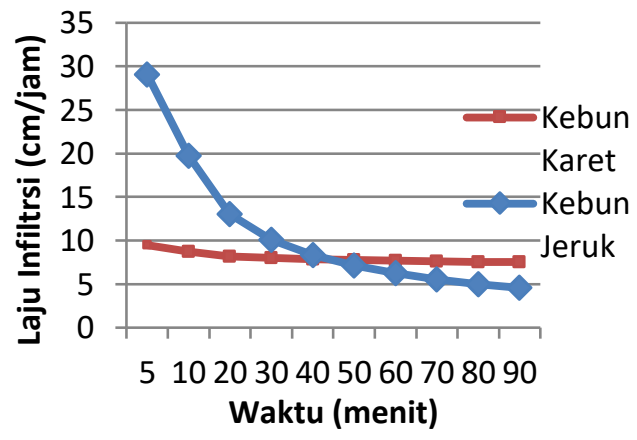

Gambar 5. Laju Infiltrasi Kebun Jeruk dan Karet Titik 1 Saat Pasang 
Sedangkan untuk melihat laju infiltrasi

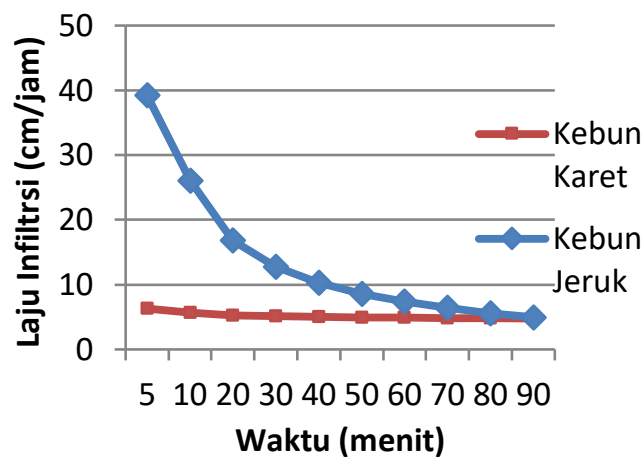

Gambar 6. Laju Infiltrasi Kebun Jeruk dan Karet Titik 2 Saat Pasang

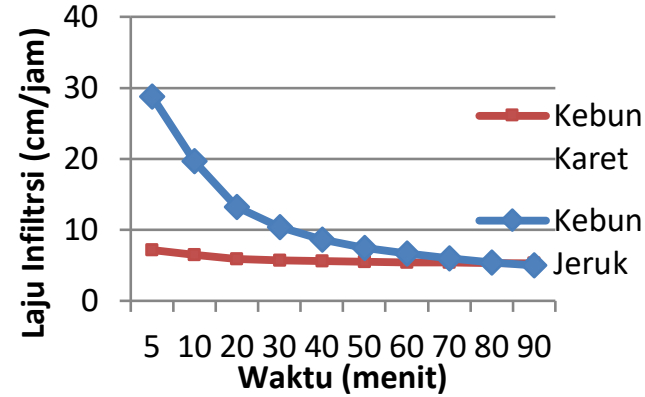

Gambar 7. Laju Infiltrasi Kebun Jeruk dan Karet Titik 3 Saat Pasang

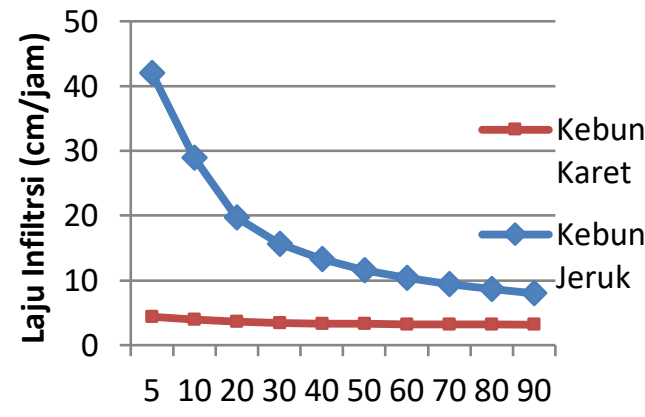

Waktu (menit)

Gambar 8. Laju Infiltrasi Kebun Jeruk dan Karet Titik 4 Saat Pasang

Dari gambar grafik batang diatas, maka laju infiltrasi tiap titik pengamatan dapat dilihat pada gambar 5. 6, 7, dan 8 yang disajikan pada gambar berikut ini, tiap titik pengamatan pada saat surut disajikan gambar 9, 10, 11 dan 12 yang berbentuk kurva dibawah ini :

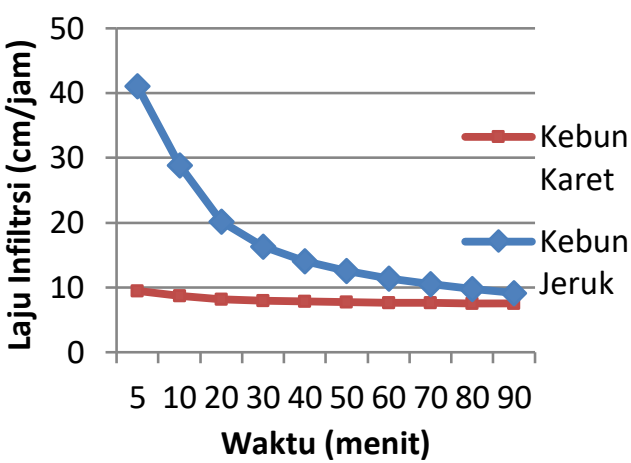

Gambar 9. Laju Infiltrasi Kebun Jeruk dan Karet Titik 1 Saat Surut

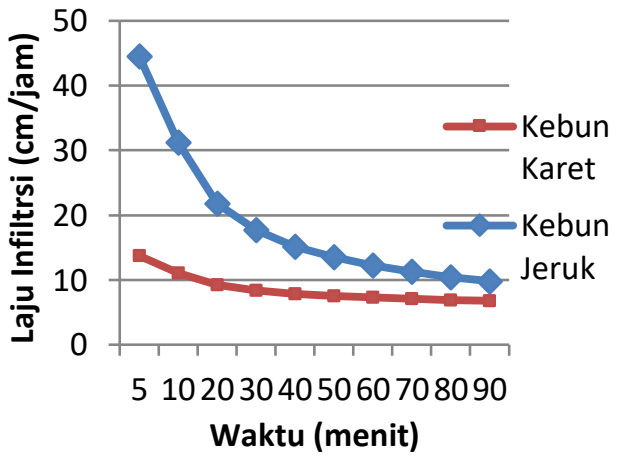

Gambar 10. Laju Infiltrasi Kebun Jeruk dan Karet Titik 2 Saat Surut

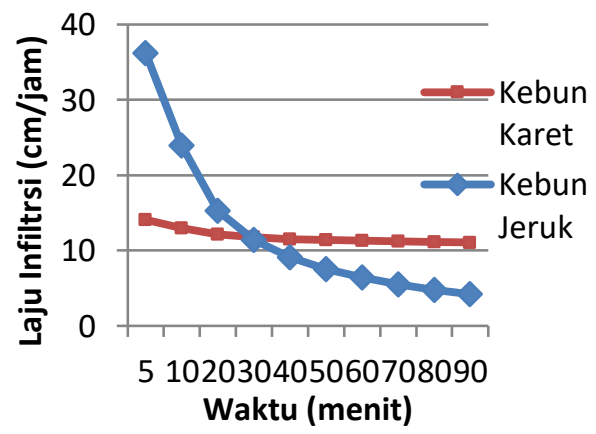

Gambar 11. Laju Infiltrasi Kebun Jeruk dan Karet Titik 3 Saat Surut 
Subagyo, H. 1997. Potensi pengembangan dan tata ruang lahan rawa untuk pertanian. h. 17-55. Dalam A.S. Karama et al. (penyunting). Prosiding Simposium Nasional dan Kongres VI PERAGI. Makalah Utama. Jakarta, 2527 Juni 1996.

Yogaswara, M.B. 2001. Analisis Laju Infiltrasi Pada Berbagai Tingkat Penutupan Lahan Areal Hutan Jati (Tectona grandis, L. f.). Institut Pertanian Bogor. Bogor

Laju infiltrasi pada kebun jeruk baik saat pasang maupun surut selalu lebih besar daripada laju infiltrasi kebun karet, hal ini dikarenakan oleh adanya vegetasi tumbuhan seperti tanaman penutup tanah jenis rerumputan sehingga menunjukkan perbedaan laju infiltrasi yang nyata. Vegetasi tanaman penutup tanah jenis rerumputan pada kebun jeruk dapat membantu dalam penyerapan dan pengikatan air tanah dan mampu memperbaiki permeabilitas tanah sehingga dapat meningkatkan volume porositas dan menurunkan bobot isi tanah.

\section{DAFTAR PUSTAKA}

Asdak, C. 2002. Hidrologi Dan Pengelolaan Daerah Aliran Sungai. Gadjah Mada University Press, Yogyakarta : xiv + $618 \mathrm{hlm}$.

Balai Penyuluh Kecamatan. 2013. Penggunaan Lahan Desa Sebawi. Kecamatan Sebawi

Dinas Pertanian Tanaman Pangan dan Hortikultura. 2007. Kalimantan Barat

Indriyanto. 2012. Ekologi Hutan. PT Bumi Aksara. Jakarta

Mahmud A. 2011. Hidrologi Teknik. Program Hibah Penulisan Buku Ajar : Universitas Hasanuddin 